\title{
Study on the Functions Evolution and Role Change of University Libraries Subject Librarian
}

\author{
Guishan Zhang ${ }^{1, a}$ \\ ${ }^{1}$ Jilin Agricultural University, Jilin, Changchun, 130118 \\ ${ }^{a}$ email
}

Keywords: University Libraries; Subject Librarian; Functional Evolution; Changing Roles

\begin{abstract}
It describes the evolution of the functions of institutions of higher learning and the Changing Role of Librarians discussed the role and functions of institutions of higher learning subject librarian, comparative analysis of the subject bibliography librarian, traditional librarian, embedded Subject Librarian Evolution of functions and roles change process. University Libraries should be pointed out that actively promote their embedded subject librarian service, to provide users with discipline, personalized, knowledgeable, ubiquitous service.
\end{abstract}

\section{Introduction}

Library is to collect, organize, preserve and disseminate scientific knowledge and information, cultural and educational institutions to carry out social education and the development of intellectual resources, it plays the role of the repository and disseminator of information, and in promoting scientific and technological progress has played a central role . Librarianship development is inseparable from the efforts and work of librarians, librarians is to enhance and realize the core values of libraries during the most active factor of creativity, information integration specialist literature, librarian, information consultant, knowledge Navigator. College Library is the school's Documentation and Information Center, The changing role of librarians clearly indicates that the University Library in the development of an important period features, as well as the urgent needs and significantly improve the content of the work of librarians and service model. This paper describes the functions of the process of evolution and the Changing Role of Universities Librarians, and noted that China should actively promote the University Library Subject Librarians and embedded service, from the user's needs, strengthening the knowledge service.

\section{The Function, Mandate and Role of University Librarians}

College Library is an academic institution for teaching and research services, librarians is to enhance and realize the core values of libraries during the most active factor in creativity.

Librarian is responsible for the procurement of Library Resources, processing, description, distribution (borrowing), professional analysis reports and reader service work, but also need education, guidance, counseling readers to use scholarly literature resources. Librarians can not be misunderstood as a librarian (or librarian), or mistakenly believe their job content but also by the work flow of the book. Librarians of Colleges and Universities by function can be divided into the interview librarian, cataloging librarian, systems librarian, reference librarian, etc., was awarded the rank of teachers or appropriate treatment. Librarians are usually divided into four ranks, assistant librarian (junior librarian), librarian, associate research librarian, research librarian, in turn is equivalent to assistant lecturer (assistant), lecturer, associate professor, professor. The general non-professional librarian, is not granted professional ranks. Librarians' quality directly affects the quality of work and level of library service, library librarian is to enhance and implement the core values of the most active and most creative factor, between librarians and readers Literature Information Resources user intermediary, a bridge and link in knowledge organization and service process, plays the role of organizer and disseminator of knowledge, information integration specialist literature librarians, librarian, information consultant, knowledge Navigator. General Academic Library Regulation explicitly regulate the librarian functions and tasks: First, the 
construction of literature information resources (including collection of physical resources and virtual resources), scientific processing of resources and management and maintenance of the entire sequence. Second, do Circulation resource transfer and reference work. Third, the Information Quality Education. Fourth, configure the organization, coordination and optimization of document information resources. Fifth, actively participate in document security system, carry out academic activities.

Subject service generally refers to Subject Librarian disciplines and various disciplines around the user's teaching, research, learning needs, contact information and transfer undertaken, in-depth information service reports, disciplinary network information navigation services, researchers tracking and SDI service, subject information literacy education. Therefore, subject librarian literature information to provide effective protection for teachers and students teaching and scientific research, making full use of the library literature, literature collections is more reasonable to carry out reference, document information for a given title search, the results of the new investigation topics, compiling information and analysis, the latest reported in the literature and other information services.

\section{Functions of the First Generation of University Libraries Subject Librarian}

From librarians, subject bibliography librarian, librarian, embedded librarian, library resources from construction, faculty liaison, customer service and the Changing Role of University Librarians clearly indicates that the library development process an important period features, as well as the urgent needs and significantly improve the content of the work of librarians and service model.

Subject librarian, namely librarian, refers to a keen sense of information, strong organizational information processing capacity of the library-level expertise. University Library System in the United States, with the exception of "Subject Librarian" this formulation, the relevant title and "liaison librarians", "Subject bibliography Librarian", "Subject counselor", "Knowledge Navigator", etc. . Early "Subject Librarian" more work is to undertake liaison department, are "subject bibliography librarian." For example, before 1940, Harvard University Library and a handful of hired subject bibliography librarian, responsible for establishing an independent subject collections. Due to the need of the war, the United States needs a deep understanding of information and culture abroad, the government began a large-scale establishment of the Institute of American University area, the establishment of library collections requires regional institutes commitment to these specific regional information and cultural preservation function, these organizations regional research collections librarian is subject bibliography librarian. From World War II, University of London, first appeared in the subject bibliography librarian.

With the ever-changing needs of the community, academic librarians work not only stay in a single contact or collection management department, but transferred to the depth of information and knowledge services, while in the transverse direction also pay more attention to and actively outreach Cooperation. Subject librarians guide book American Library Association in 2001 compiled by the definition given, subject librarian's job is with the user library resources assessment and improve the collection of user needs satisfaction process along. The general consensus is that we, the United States launched a massive World War II started to build the Subject Librarian System in the Academic Library, and the establishment of subject librarian positions. In 1964, the British proposed in British university libraries all hiring Subject Librarians. Germany after World War II, a massive increase in jobs subject librarian. The first generation of the Subject Librarian (traditional subject librarian) main function is collection development, reference, faculty contact, cataloging, bibliography and literature blog learning guide the preparation of, and promote exchanges and academic libraries, enhanced the library user-oriented image. In 1998, he established the Tsinghua University Library Subject Librarian System and the establishment of LIS faculty hired experts, first in the country began a subject librarian for library services disciplines. Subsequently, the Xi'an Jiaotong University in University Library and other libraries to follow established subject librarian (or subject librarians) system, carried out by the person responsible for specific departments and disciplines, targeted services, just discipline Museum members of job functions with different 
emphases. Since 2003, Tsinghua University Library to further expand the functions of subject librarians, launched the discipline of competitive intelligence for analytical services. In 2006, the Chinese Academy of Sciences National Science Library launched "into the line, the embedding process, to provide discipline, personalized, knowledgeable, ubiquitous services," the "second generation subject librarians and subject service."

\section{Function of the Second Generation of University Libraries Subject Librarian}

Faced with changes in user needs and new environment, the traditional subject librarians need for the progressive development of embedded librarian, library services to adapt to the pattern and mechanism innovation.

Functions embedded Subject Librarians Subject Librarian American University initially mainly engaged in the purchase of literature, reference, subject cataloging work, followed by the "book object" to "user objects." The development and dissemination of knowledge of the network spread of information technology, the need to subject librarian from a large number of information resources is carried out according to need to collect, filter, sort, extract knowledge extraction process integrated into products from a variety of explicit and implicit knowledge resources extract information and knowledge needs of teachers and students, provide in-depth knowledge of the service. Embedded Librarians, namely embedded librarian, due to the war in Iraq during the term "embedded" into the Iraqi army were news reporters follow-up reports of countries belonging to the second generation of the Subject Librarian. In 2004, Kearley and Phillips first proposed "Embedded Subject Librarian" concept, and is used to summarize the important role librarians play online course. In 2007, Shumaker put forward from co-localization (Co-location), partnerships (relationships), joint management (Co-management), co-funded (Co-funding) to understand the four dimensions of the embedded library services, he thinks embedding formula is subject librarian librarian in the extended period of time can be dedicated to a user (group) services. In 2006, the National Science Library the creation of a "into line, the embedding process" as a symbol of the second generation of Subject Librarian Service Mode. Embedded Librarian service is a new service model, is a new area of research, the embedded subject librarian is considered to be the further development of subject librarians, the second generation of the Subject Librarian. Since 2007, a number of colleges and universities around the library subject service users began to explore embedded teaching and research. 2012 curator Zhang Xiaolin on Subject Librarian Service Seminar proposed to "user - based, covering the intellectual capacity to embed teaching and research process, what you need" is the essence of discipline embedded service. University Library in developed countries have better implementation of embedded services and embedded Subject Librarian System. China has gradually developed a library of embedded Service Mode phone based, RSS service model, service model community site, "e zoned" service mode embedded services.

Subject Librarian generations only relative. The second generation subject librarian work is an extension of the first generation of subject librarians and deepening, but the service in place, respect the logical starting point, depth, content, tools, responsibility, role orientation, etc., with the first generation of Subject Librarians essentially different.

\section{Conclusion}

University Libraries is an academic institution for teaching and research services, librarians is to enhance and realize the core values of libraries during the most active factor in creativity. With the evolution of the functions of University Librarians and the Changing Role, China should actively promote the University Library Subject Librarians and embedded services, from the user needs to provide discipline, personalized, knowledgeable, ubiquitous service .

\section{References}

[1] Yang Junhui, Liu Xianju, Guo Yue. Disciplines of library service platform, Hunan University 
Library of Medicine, 2014, 14, (1): 50-52.

[2] Li Wenwen, Chen Ya. Embedded library service model Study [J]. Journal of Academic Libraries, 2011. 1. 90-92.

[3] Cao Jingren, Li Hong. Subject knowledge embedded in the library under the service environment [J]. Library Tribune, 2011.31 (3) 117-119.

[4] Chen Fangning. Knowledge Service Practice and Enlightenment of American University Library Subject Librarian [J]. New World Library, 2013. 1. 81-83.

[5] Mo Qiqiang. University Library Subject Service Discussion [J]. Library Work and Study, 2011. 7. 85-89. 